\title{
PELATIHAN PENGOLAHAN DATA PENELITIAN MENGGUNAAN SOFTWARE EXCEL
}

\author{
Research Data Processing Training Using Excel Software \\ Ingka Rizkyani Akolo' ${ }^{1)}$, Rosdiani Azis ${ }^{2)}$ \\ ${ }^{1,2)}$ Staf Pengajar Program Studi Teknologi Hasil Pertanian Politeknik Gorontalo \\ Jl. Muchlis Rahim Desa Panggulo, Kecamatan Botupingge, Bone Bolango, Gorontalo \\ E-mail : inkarizkyani05@gmail.com
}

\begin{abstract}
ABSTRAK
Setiap mahasiswa pada perguruan tinggi diwajibkan untuk melakukan penelitian sebagai syarat lulus di perguruan tinggi tersebut. Penelitian biasanya tidak lepas dari istilah pengolahan data. Setiap mahasiswa diharapkan dapat menyelesaikan penelitiannya tepat waktu dengan hasil yang maksimal. Akan tetapi, mahasiswa seringkali kesulitan dalam melakukan pengolahan data penelitian, terutama jika dihadapkan dengan rumus yang cukup rumit dan memakan waktu yang banyak jika diselesaikan secara manual. Oleh karena itu, pelatihan ini merupakan salah satu cara untuk membantu mahasiswa saat mengolah data penelitian sehingga tugas akhir mahasiswa dapat diselesaikan tepat pada waktunya. Secara keseluruhan kegiatan ini berjalan dengan baik, sebagian besar peserta mampu menerima materi dengan baik. Peserta juga aktif dalam seluruh proses kegiatan khususnya pada saat simulasi.
\end{abstract}

Kata kunci : pengolahan, data, mahasiswa

\begin{abstract}
Every student at a university is required to conduct research as a graduation requirement in the college. Research usually cannot be separated from the term data processing. Every student is expected to complete his research on time with maximum results. However, students often have difficulty to processing research data, especially if data processing have a complicated formula and takes a lot of time if done manually. Therefore, this training is one way to help students when processing research data so that the final assignments of students can be finished on time. Overall this activity went well, most participants were able to receive the material well. Participants are also active in all process activities, especially during simulation.
\end{abstract}

Keyword : processing, data, software, students 


\section{PENDAHULUAN}

Salah satu kompetensi yang harus dimiliki oleh mahasiswa semester akhir adalah mampu melakukan penelitian supaya bias lulus dari sebuah perguruan tinggi. Penelitia nmerupakan suatu bentuk kegiatan ilmiah untuk mendapatkan pengetahuan atau kebenaran. Ada dua teori kebenaran pengetahuan, yaitu teori koherensi dan korespondensi. Teori koherensi beranggapan bahwa suatu pernyataan dikatakan benar apabila sesuai dan tidak bertentangan dengan pernyataan sebelumnya. Aturan yang dipakai adalah logika berpikir atau berpikir logis. Sementara itu teori korenspondensi berasumsi bahwa sebuah pernyataan dipandang benar apabila sesuai dengan kenyataan (fakta atau realita). Untuk menemukan kebenaran yang logis dan didukung oleh fakta, maka harus dilakukan penelitian terlebih dahulu (Ditjen PMPTK, 2008).

Pengolahan dan analisis data merupakan tahapan penting dalam penelitian. Data yang telah dikumpulkan tidak akan berarti apa-apa bila tidak diolah dan dianalisis, untuk menghasilkan kesimpulan. Analisis data tidak saja membutuhkan keterampilan teknis pengerjaan yang sesuai dengan jenis data, namun juga referensi untuk dapat memaknai data yang ada (Antara, 2012).

Dalam analisis data, umumnya diperlukan alat analisis yang dikenal dengan statistika. Hasil analisis statistika dari sekelompok data akan memudahkan peneliti menginterpretasikan data atau mengambil kesimpulan dari permalahan yang dipelajari atau diteliti. Dengan demikian, seorang peneliti haruslah memahami bidang ilmu statistika karena dengan statistika peneliti dapat merancang suatu penelitian, merencanakan cara analisis data, dan memudahkan dalam menyimpulkan hasil penelitian. Data dihasilkan dari pengamatan atau pengukuran dari proses penelitian yang dirancang dari awal dengan metode penelitian yang benar (Nurhadi, dkk., 2015).

Dalam penyusunan tugas akhir penelitian mahasiswa seringkali mengalami kesulitan, terutama dalam mengelola dan menganalisis data penelitian sehingga data dapat diinterpretasikan dalam sebuah kalimat. Hal yang sama juga dirasakan oleh Mahasiswa Politeknik Gorontalo. Keterbatasan waktu dalam proses belajar mengajar menyebabkan mahasiswa kurang mampu menyerap ilmu yang diberikan, terutama tentang statistika yang berkaitan dengan pengolahan data khususnya dengan menggunakan software. Software dapat memudahkan mahasiswa untuk mengolah data dan memperoleh hasil yang lebih akurat.

Berdasarkan latar belakang di atas, maka akan dilakukan Pelatihan Pengolahan Data Penelitian menggunakan Software untuk mahasiswa Politeknik Gorontalo. Tujuan dari pelaksanaan kagiatan pengabdian ini adalah untuk melatih keterampilan mahasiswa dalam mengolah data penelitian sehingga memudahkan proses penyusunan tugas akhir mahasiswa.

Setiap mahasiswa semester akhir pada perguruan tinggi diwajibkan untuk melakukan penelitian sebagai syarat untuk menyelesaikan kuliah di perguruan tinggi tersebut, begitu juga di kampus Politeknik Gorontalo. Penelitian tentunya tidak lepas dari istilah pengolahan data dan penggunaan metode penelitian yang tepat. Setiap mahasiswa diharapkan dapat menyelesaikan penelitiannya tepat waktu dengan hasil yang maksimal dan dapat dipertanggungjawabkan. Akan tetapi, mahasiswa seringkali kesulitan dalam melakukan pengolahan data penelitian, terutama jika dihadapkan dengan rumusrumus yang cukup rumit dan memakan waktu yang banyak jika diselesaikan secara manual. Oleh karena itu, pengabdian ini merupakan salah satu cara untuk membantu mahasiswa dalam melakukan pengolahan data penelitian 
sehingga proses penyusunan tugas akhir dapat diselesaikan tepat pada waktunya.

\section{SOLUSI DAN TARGET LUARAN}

\section{Solusi}

Salah satu solusi dari permasalahan yang terjadi yaitu dengan adanya pelatihan tersebut mahasiswa akan mendapatkan pelatihan secara langsung bagaimana cara mengolah data menggunakan software yang ada.

Tujuan pelaksanaan kegiatan pelatihan ini adalah sebagai berikut

1. Mahasiswa dapat melakukan proses penelitian dengan jujur dan benar

2. Mahasiswa dapat mengolah data penelitiannya sesuai dengan desain penelitian yang digunakan dalam proposal

3. Mahasiswa mempertanggungjawabkan dan mempertahankan data penelitian dengan tegas dan lugas dapat menginterpretasikannya.

Luaran Yang Diharapkan :

1. Menghasilkan SDM yang lebih produktif dan terampil dalam mengolah data penelitian

2. Menambah pengetahuan mahasiswa tentang metode pengolahan data yang ada khususnya pengolahan data menggunakan software tertentu.

\section{METODE PELAKSANAAN}

Saat pelaksanaan program, tidak hanya materi dalam bentuk audio visual yang akan diberikan namun peserta juga akan diberikan manual/panduan bagaimana pengolahan data menggunakan software. Diharapkan setelah kegiatan ini, mahasiswa dapat mengolah data penelitiannya dengan baik dan benar. Pengabdian Masyarakat ini dilaksanakan di Politeknik Gorontalo pada bulan Desember 2017.

\section{Alat dan Bahan yang digunakan dalam pelatihan}

Alat dan bahan yang digunakan dalam pelatihan ini adalah: laptop, spidol, modul pelatihan.

\section{Prosedur Pelaksanaan}

Adapun kegiatan-kegiatan yang dilakukan secara garis besar adalah sebagai berikut:

1. Penjelasan Materi Statistika

Sesi pelatihan ini menitikberatkan pada teori statistik dan beberapa metode yang dapat digunakan dalam menganalisis data penelitian, serta penjelasan beberapa software yang dapat digunakan untuk mengolah data penelitian.

2. Tutorial dan Simulasi

Pada sesi pelatihan ini peserta diajarkan cara-cara mengolah data menggunakan software dan langsung dapat dipraktekkan dilaptop masingmasing menggunakan contoh data penelitian yang ada dimodul pelatihan.

\section{HASIL DAN PEMBAHASAN}

Kegiatan pelatihan pengolahan data menggunakan software bagi mahasiswa Politeknik Gorontalo yang dilaksanakan di Politeknik Gorontalo Kabupaten Bone Bolango pelaksanaanya terjadwal, dan berjalan sesuai rencana. Pelaksanaan kegiatan dilaksanakan pada pekan ke-3 bulan Desember sebanyak 2 hari. Pertemuan tatap muka diberikan dengan cara ceramah konsep-konsep dasar statistika untuk keperluan penelitian, disertai contoh-contoh penelitian kuantitatif. Kegiatan dilanjutkan dengan praktik pengenalan software Ms.Excel dan function yang digunakan saat mengolah data. Pelaksanaan kegiatan dilakukan di labolatorium Teknologi Hasil Pertanian. Pelaksanaan kegiatan pengabdian ini dilakukan oleh dua orang tim pengabdi yang berasal dari program studi Teknologi Hasil Pertanian (THP). 


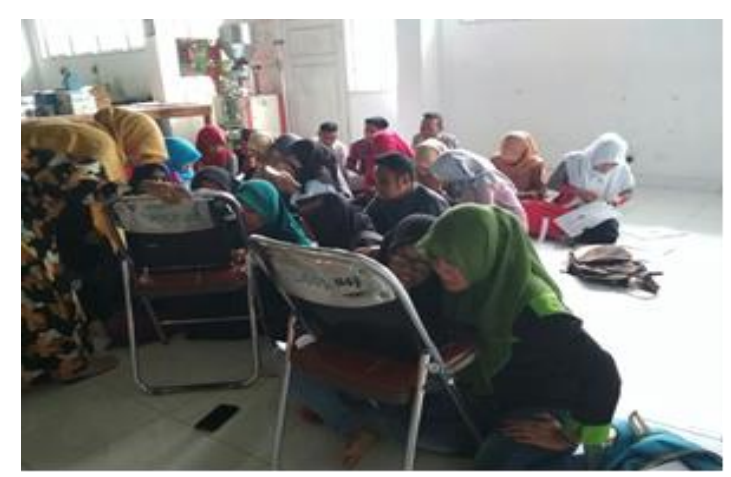

Kegiatan dilaksanakan secara bertahap mulai dari persiapan peserta khususnya persiapan untuk laptop yang akan digunakan untuk praktik nanti, kemudian dilanjutkan dengan pembagian modul tutorial untuk mengolah data. Setelah itu dilanjutkan dengan pemaparan konsepkonsep tentang data, statistika, metode penelitian yang biasa digunakan, kemudian dilanjutkan dengan simulasi/praktik dari konsep yang diberikan. Data yang dihasilkan dari penelitian baik itu survey maupun percobaan adalah dalam bentuk data kasar. Seringkali data tersebut belum sesuai dengan asumsi atau tipe analisis yang digunakan. Dalam melakukan analisis data, data kasar harus diolah terlebih dahulu untuk memperoleh data yang siap untuk dianalisis. Data hasil penelitian dapat dilakukan transformasi untuk dapat dilakukan analisis statistik yang benar. Dengan demikian analisis data dapat menghasilkan informasi yang bermanfaat

Software yang digunakan dalam kegiatan pengabdian ini adalah software Microsoft Excel. Microsoft Excel merupakan salah satu program dari Microsoft yang memiliki banyak kegunaan. Salah satu kegunaannya adalah bisa berguna untuk coding data, transformasi data dan mengolah data penelitian menggunakan beberapa metode dalam statistika. Pengolahan data menggunakan cara yang manual (perhitungan kalkulator) tentunya membutuhkan waktu yang cukup lama, selain itu perhitungan manual membutuhkan nalar dan analisis yang tinggi agar mampu menerjemahkan rumus yang ada dan menghitung data menggunakan kalkulator. Microsoft Excel memberikan solusi yang cukup bagus untuk mahasiswa yang akan mengolah data penelitiannya, khususnya jika data penelitiannya menggunakan metode statistika yang ada fungsinya (function) di Microsoft Excel.

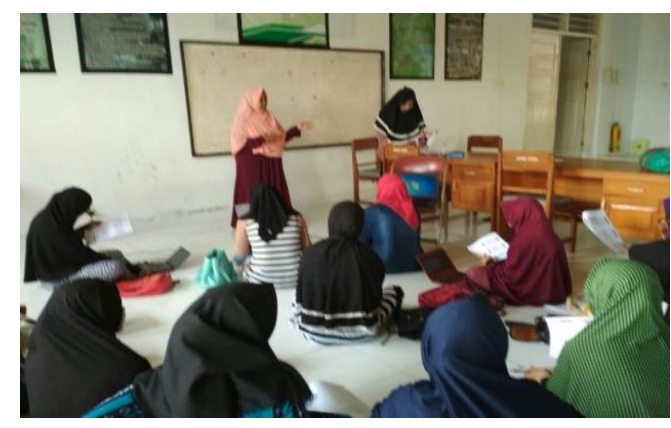

Pada saat kegiatan berlangsung, peserta mengikuti kegiatan dengan antusias, hal ini ditunjukkan dengan banyaknya pertanyaan dan tanggapan mengenai materi yang diberikan. Sebagian besar peserta lebih banyak menanyakan tentang konsep data penelitian, contoh data penelitian dalam bidang industry, metode penelitian yang sering digunakan dalam penelitian kuantitatif dan cara pengolahan data yang mudah tapi mampu memberikan hasil yang maksimal. Peserta juga menanyakan cara menginterpretasikan output Microsoft Excel dan cara menghubungkannya dengan kasus yang mereka teliti.

Ketercapaian tujuan kegiatan Pelatihan ini sudah baik, hal ini dapat dilihat dari pemahaman peserta mengenai kesesuaian alat statistik dengan permasalahan penelitian, dan kemampuan peserta menganalisis data dilihat hasil latihan yang diberikan oleh pelaksana kegiatan. Ketercapaian materi yang diberikan cukup baik sebagian besar peserta sudah menguasai materi dengan baik, hal ini juga didukung observasi dari pelaksana di kelas dan labolatorium.

Kemampuan peserta dalam penguasaan materi sudah baik yang ditunjukkan kemampuan dari peserta dalam menyelesaikan tugas yang diberikan oleh 
pelaksana dengan baik. Peserta juga mampu menjawab dengan baik setiap pertanyaan-pertanyaan yang diberikan oleh pelaksana kegiatan. Secara keseluruhan peserta puas dengan kegiatan yang sudah dilaksanakan, peserta merasa terbantu dengan adanya kegiatan ini karena peserta membutuhkan kegiatan ini sebagai bagian kompetensi dalam melakukan penelitian khususnya dalam penyusunan tugas akhir. Sebagian peserta antusias untuk mengikuti kegiatan dengan memberikan saran melanjutkan kegiatan di lain hari dengan waktu pelatihan yang lebih lama, serta kelanjutan program pelatihan untuk konsep statistik lanjutan dan program statistik lainnya seperti penggunaan konsep Rancangan Percobaan dan Quality Control menggunakan software SPSS dan Minitab.

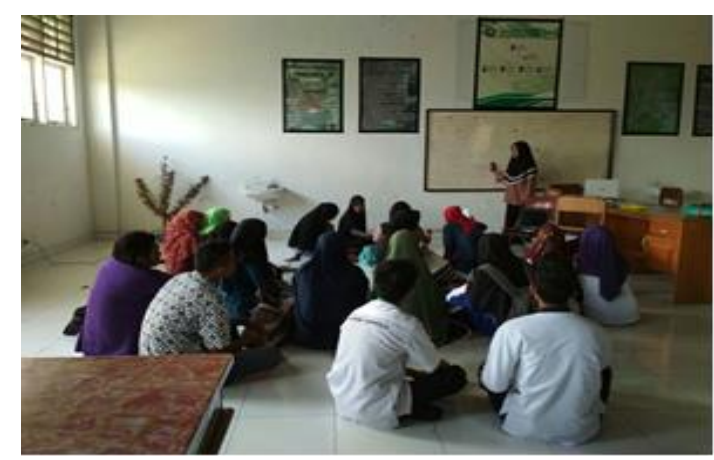

Pelatihan pengolahan data bagi mahasiswa dalam program pengabdian ini diharapkan dapat memberikan pemahaman dan juga kemampuan kepada mahasiswa untuk tidak lagi menggunakan cara manual dalam mengolah data penelitian. Mahasiswa sudah dapat memanfaatkan software yang ada, misalnya Microsoft Excel untuk mengolah data penelitian yang ada. Hal ini tentunya akan memberikan dampak positif bagi mahasiswa berupa meminimalisir waktu penyusunan tugas akhir serta mampu memberikan hasil yang lebih akurat dan dapat dipertanggungjawabkan.

\section{KESIMPULAN DAN SARAN}

Secara keseluruhan kegiatan pelatihan pengolahan data penelitian menggunakan software ini berjalan dengan baik dan lancar. Sebagian besar peserta mampu menerima materi dengan baik. Peserta juga aktif dalam seluruh proses kegiatan khususnya pada saat simulasi.

\section{DAFTAR PUSTAKA}

Antara, N.S. 2012. Pengolahan dan Analisis Data. Bali: Udayana

Ditjen PMPTK. 2008. Pengolahan dan Analisis Data Penelitian. Jakarta: PMPTK.

Nurhadi, dkk. 2015. Pelatihan Program Statistic Bagi Guru-Guru Sekolah Menengah Atas (SMA) di Daerah Istimewa Yogyakarta. Yogyakarta: UNY. 